\title{
Methodology Forming Strategies for Management of Commercial Resources of Trading Enterprises
}

\author{
Olga Guseva, Svitlana Lehominova, Ruslan Dymenko, \\ Olena Voskoboeva, Olga Romashchenko \\ State University of Telecommunications \\ 03110, Solomenska st. 7, Kievo \\ Ukraine
}

\begin{abstract}
The development of methodical approach to strategy formation of inventory management of trede enterprises. The aim of the paper is to develop a methodical approach to determining strategies for managing inventory on which may provide synchronization between the processes of formation of inventory and sales. Implementation of the proposed approach to study inventory management strategies will ensure synchronization between the processes of formation efficiency and effectiveness of inventory sales. Considered the impact of the most important factors, which we have identified, as forecast changing of population demand, quality inventory control and to determine the private areas within the overall strategy towards inventory management, describing the pursuit of optimization of inventory in the activities of commercial enterprise.
\end{abstract}

Keywords: inventory, trading company, inventory management, strategy, class procedures, functional model, cybernetic approach, stratagem.

\section{INTRODUCTION}

An important step in the process of inventory management is to define strategies for managing them. Inventory management can be successful, if at any time the trading enterprise has a need for the sale of goods.

When choosing a strategy for managing inventory of commercial enterprise costs play a major role in their formation. Inventory management is usually carried out under different constraints: deadlines for orders and their implementation, depending on the scope of the party purchasing goods, and depending on the level of inventories.

This necessitates a strategic approach to inventory management based on the most significant and influential factors.

\section{PROBLEM FORMULATION}

Theoretical aspects of inventory management of retail trade enterprises are disclosed in the works of local scientists -I.I. Korolkova , M.D. Winogradsky, P.Y. Balaban, I.A. Blanc, A. A. Mazaraki , L.A. Lihonenko , foreign scholars Bukan J., E. Kenigsberg, P.Zermati , Milhroa P., J. Roberts , M. Darbinyan, L.P. Nagovitsin, U.P Hryzanova , Y. Ryzhykov, V.I. Sergeyev , A. Hadzhynsky, et.

However, a lot of theoretical and methodical study and selection of the optimal strategy for inventory management need further depth of improvements.

Therefore, it is necessary is to develop a methodical approach to determining strategies for managing inventory on which may provide synchronization between the processes of formation of inventory and sales.

\section{PROBLEM SOLUTION}

The study showed that the overall strategy during inventory management understand the set of rules by which decisions are made at the strategic and operational planning, monitoring and adjusting a set of parameters which associated with stocks [1, s.498].

However, focusing on the relationship of the various levels of government this definition, from our point of view are not clearly separates rules. The strategic goals of inventory management are dependent on overall strategic objectives of 
commercial enterprises, which may be an increase in the consumer market segment, increasing equity and the market value of the enterprise, increase profits and profitability, improving range, increased trade service and others.

As the strategic objectives of inventory control A.A. Mazaraki, L.A. Lihonenko, I.A. Blank and several other distinguished: sustainable range and rhythmic exercise trading process, the accumulation of products of seasonal demand and purpose, the implementation of speculative trading in bulk commodities during periods of favorable trading conditions and to prevent impairment of available free cash assets in an inflationary economy under [4, p.188].

Being in essence true, such a formulation in our view does not reflect a systematic approach to inventory management. It seems more precise definition of the strategic goal of inventory management as the organization smooth trading at the lowest cost and maximum satisfaction of consumer demand.

Strategies of inventory management are varied; most of them depend on the tactics of management indicators of demand, supply planning, and analytical study of the combination of a multitude of market performance. In the economic literature there are the following types of inventory management strategies $[2,3]$ :

Strategy of greatest caution. According to this strategy, the required reserve amount is calculated by multiplying the maximum consumption of inventory (under any heading) for one day for the longest period of supply. As a result, creates inventory that cannot practically be fully used until the next execution of orders for their replenishment. It should be noted that this market strategy of inventory management, generating the formation of the remaining inventory of goods movement system, so the more applicable in the form of small logistics systems.

The strategy of additional reserves. Warranty requirements provided in this case by creating additional reserves of material resources. The value of additional reserves determined by one of the following methods:

Method 1. The size of the allowance is determined depending on the size of the average demand multiplied by the average of the implementation period, adjusted by a factor of safety, usually accepted value in the range of 25$40 \%$.
Method 2. A reserve unit of inventory is determined as a measure of the square root of the average value of goods for the period.

It should be noted that in the economic literature [5] isolated as a strategy based on the use of indicators of demand from the consumer market. Such a strategy is "Strategy percent of the demand," which is based on a study of the frequency of demand for certain inventories in the course of a given time period.

These accounted for on an accrual basis, in a graphic display of the demand curve and by identifying buffer that can be spent without disturbing the operation of the system reliability.

Studies have shown that nowadays quite common the following basic strategies of inventory management: strategy «Just in time» (depending on needs); SIC (statistical inventory control); strategy to replenish inventories of the period and the size of the order.

In determining the vector of strategic inventory management is quite important thing is also to choose the method of formation control of inventory: «lot for lot» or « a purchase order ", to a maximum replenishment of inventory, order a fixed amount of inventory or method «to order» - under order.

Table 1 Key characteristics of modern basic inventory management strategies of commercial enterprises

\begin{tabular}{|c|l|}
\hline $\begin{array}{c}\text { Title basic of } \\
\text { strategy }\end{array}$ & \multicolumn{1}{|c|}{ Description of strategy } \\
\hline \multirow{3}{*}{$\begin{array}{c}\text { Just in time } \\
\text { (depending on } \\
\text { the needs) }\end{array}$} & $\begin{array}{l}\text { formed a "safety stock" (Safety } \\
\text { stock) to the extent necessary for } \\
\text { a certain time, or determined by } \\
\text { the "order point" (reorder point) - } \\
\text { which has been reached when } \\
\text { necessary make an order to the } \\
\text { supplier, and "replenishment rate" } \\
\text { and balance - of inventory above } \\
\text { which it is not recommended to } \\
\text { raise the level of inventory } \\
\text { warehousing particular product. }\end{array}$ \\
\hline SIC (statistical \\
inventory \\
management)
\end{tabular} \begin{tabular}{l}
$\begin{array}{l}\text { Involves the application of } \\
\text { statistical methods in modeling } \\
\text { demand and replenishment time } \\
\text { of inventory. Under this strategy, } \\
\text { the need for repeated between } \\
\text { points of order established based } \\
\text { on the maximum level of } \\
\text { inventory in stock that will } \\
\text { provide the maximum satisfaction } \\
\text { of consumer demand, and for }\end{array}$ \\
\hline
\end{tabular}




\begin{tabular}{|c|c|}
\hline & $\begin{array}{l}\text { commercial enterprises - ensuring } \\
\text { maximum return on inventory. }\end{array}$ \\
\hline $\begin{array}{l}\text { «Minimum- } \\
\text { maximum» } \\
\text { (strategy to } \\
\text { replenish } \\
\text { inventory } \\
\text { with period } \\
\text { and size } \\
\text { of the order) }\end{array}$ & $\begin{array}{l}\text { This strategy of inventory } \\
\text { management (s, S) has two } \\
\text { governing parameters: lower } \\
\text { (critical) stock level s and upper } \\
\text { stock level S. } \\
\text { If after } \mathrm{x} \text { denote the value of } \\
\text { stocks before deciding on their } \\
\text { recruitment, through } \mathrm{z}-\mathrm{value} \\
\text { replenishment, and because } \mathrm{y}=\mathrm{x} \\
+\mathrm{z} \text { - value stocks after updating, } \\
\text { the inventory control strategy (s, } \\
\mathrm{S} \text { ) is defined conditions: } \\
\qquad y(x)=\left\{\begin{array}{c}x \text { at } x>s \\
S \text { at } x \leq>s\end{array}\right. \\
\text { Thus, replenishment of } \\
\text { inventories does not occur if the } \\
\text { level is greater than critical, that is } \\
\mathrm{s} \text {; If the level that is less than or } \\
\text { equal to } \mathrm{s} \text {, then the decision is } \\
\text { made to replenish the upper level } \\
\mathrm{S} \text { so that replenishment quantity is } \\
\text { equal to: } \mathrm{z}=\mathrm{S}-\mathrm{x} \text {. }\end{array}$ \\
\hline
\end{tabular}

Compiled by the author based on the generalization $[5,6]$

Through the choice of a particular method of forming inventory management trading enterprise is committed to achieve optimal levels. Consequently, the pursuit of minimum or optimal level of inventory can be represented us via integrated inventory management strategy in the general direction of optimization of inventory based relationship management, settlement procedures and complex classes (Fig. 1).

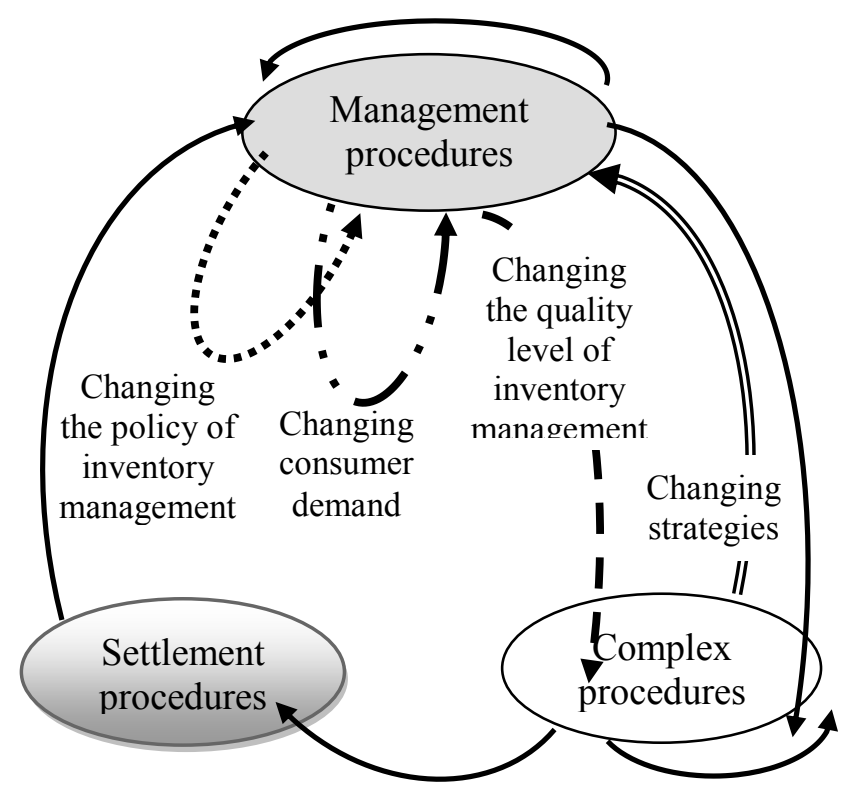

\section{Legend:}

$\longrightarrow$ - logical sequence of procedures;

$\Longrightarrow$ - sequence of procedures for policy change;

$\boldsymbol{-} \rightarrow$ - sequence of procedures for changing the quality level of inventory management;

$\ldots$. - sequence of procedures for change management policies of inventory;

- $\rightarrow$ - sequence of procedures for changing conditions in consumer

Figure 1 - Graphical representation of the relationship of class procedures, strategic management cycle inventory of commercial enterprise (Compiled by the authors).

Graphical representation of the impact of all factors that determine the type and direction of inventory management strategy is shown in Figure 2.

Given the proposed approach to building strategies of inventory management to determine the mechanisms and methods of managerial influence can be used a tool like stratagem. 


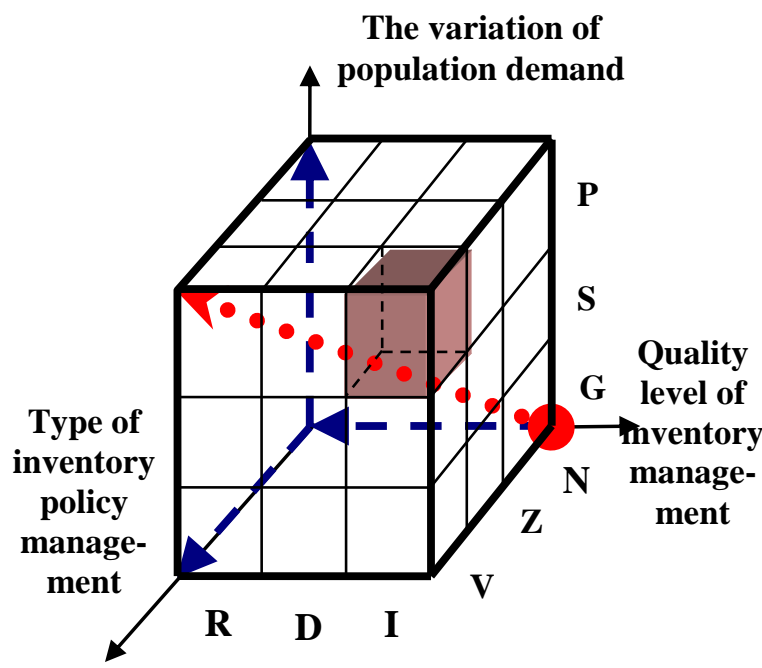

Legend:

$-\rightarrow$ impact of private factors to the positive direction of the strategy inventory management;

... - overall impact factors for positive direction control strategies inventory; - demonstrates the formation of $k$ strategy of inventory management

\section{R - Stochastic $\quad N$ - Unsatisfactory P - Progressive D-Dominant $\quad Z$-Satisfactory $\quad$ S-Static I-Integrated $\quad$ V-High $\quad$ G-Digressive}

Figure 2 - 3-component model to determine the type of inventory management strategy (Developed by the author).

To meet the challenges of economic enterprise management has been used for the first time stratagem by V. Tarasenko for the purpose of research and evaluation processes of co-evolution of leadership and environment. According to the proposed approach the development factors are based on the model "64 stratagem", which is based on cybernetic model of organization. This model is based on the analogy between biological processes which control organisms and groups of people based on structure, forward and backward linkages. [2]

Based on the ideas of S. Bir and taking into account the proposed approach Vladimir Tarasenko, in the article is developed functional model of stratagem that describe the following relationship:

$$
F=\left\langle D^{P S G} ; P_{U T Z}^{R D I} ; R_{K U T Z}^{N Z V}\right\rangle
$$

where, $D^{P S G}$ - forecast direction of change of public demand (progressive, static, digressive);

$R_{K U T Z}^{N Z V}$ - quality level of inventory management: unsatisfactory, satisfactory,high;

$P_{U T Z}^{R D I}$

TTZ - type of inventory policy management of trade enterprise: stochastic, dominant, integrated.

In graphical form inventory stratagem of commercial enterprise can be represented as follows (Fig. 3).

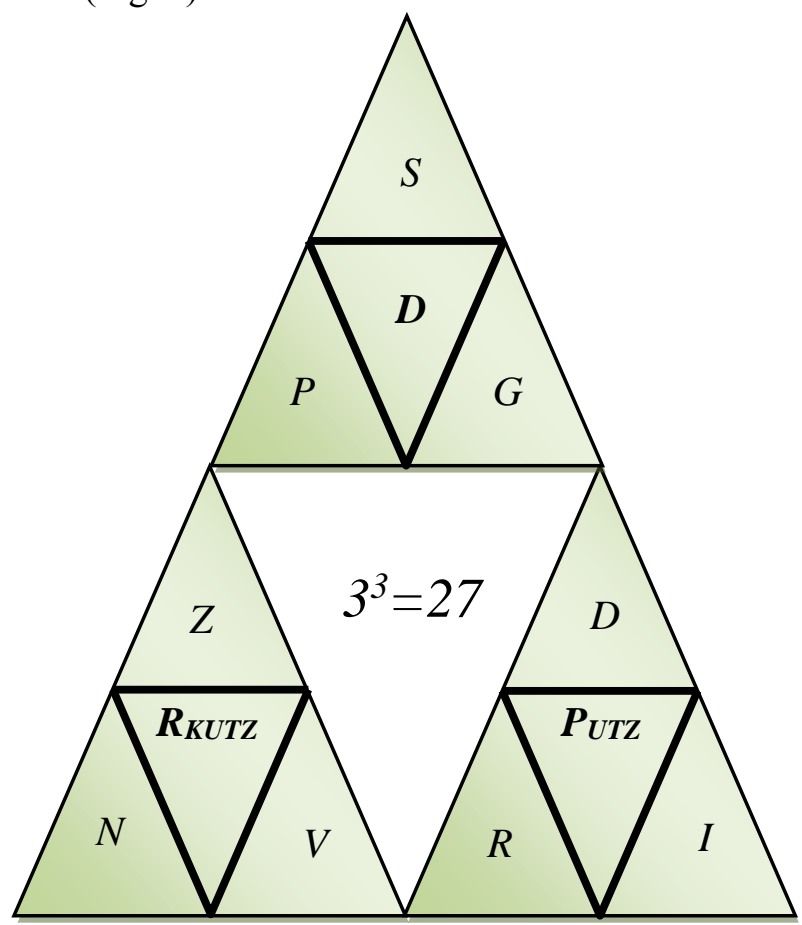

Legend:

D - predictive focus of changing demands of the population (P - progressive, $S$ - static, $G$ - digressive);

$\boldsymbol{R}_{\text {KUTZ }}$ - quality level of inventory management $(N$ - unsatisfactory, $Z$ satisfactory, V - high);

$\boldsymbol{P}_{U T Z}$ - type of inventory policy management of trade enterprise $(R$ - stochastic, $D$ dominant, $I$ - integrated).

Figure 3 - Graphical models form of formation inventory stratagems (Developed by the author).

Submitted functional model according to the cybernetic approach demonstrates the diversity that creates conditions for $\mathrm{N}^{\mathrm{k}}$ states in sensorium. In the developed model $\mathrm{N}=3$ and $\mathrm{k}=3$, since each of the three components of a functional model can have three possible states. 
Depending on the capacity and type of strategies is determined by the type of inventory management strategy. As possible alternative strategies for inventory management, the following: proactive, inertia, dissipation, convergent, sanational.

Characteristics of the strategies presented in Table 2.

Implementation of the proposed approach to study inventory management strategies will ensure synchronization between the processes of formation efficiency and effectiveness of inventory sales.

Table 2 Characteristics of inventory management strategies and their relationship to stratagem

\begin{tabular}{|c|c|c|}
\hline $\begin{array}{c}\text { Title of } \\
\text { inventory } \\
\text { management } \\
\text { strategy }\end{array}$ & Description of strategy & \begin{tabular}{|c|} 
List of \\
stratagems \\
that shape \\
strategy \\
\end{tabular} \\
\hline Proactive & $\begin{array}{l}\text { The strategy is } \\
\text { characterized by an } \\
\text { innovative orientation. } \\
\text { The basic framework for } \\
\text { implementing the } \\
\text { strategy is the use of } \\
\text { concepts: } \\
\text { 1) DDT-Effective } \\
\text { Customer Response } \\
\text { (ECR) - "An effective } \\
\text { response to consumer } \\
\text { demands»; } \\
\text { 2) Vendor } \\
\text { Managed Inventory } \\
\text { (VMI) - «Supplier } \\
\text { inventory management" }\end{array}$ & $\begin{array}{c}D V P ; I V S \\
I Z P \\
I V P\end{array}$ \\
\hline Inertial & $\begin{array}{l}\text { Characterized by } \\
\text { traditional methods of } \\
\text { forming and inventory } \\
\text { management (through } \\
\text { the use the } \\
\text { replenishment system of } \\
\text { inventory with fixed } \\
\text { period and size of the } \\
\text { order, depending on } \\
\text { their needs refill) }\end{array}$ & $\begin{array}{c}R V P ; I V G ; \\
I N P ; D V S \\
D Z P ; I Z S\end{array}$ \\
\hline Dissipative & $\begin{array}{l}\text { Characterized by quite } \\
\text { effective organization of } \\
\text { movement of trade flows } \\
\text { in the enterprise, the } \\
\text { cooperation with } \\
\text { suppliers (which most } \\
\text { are permanent). } \\
\text { However, do not trust to } \\
\text { the new range of } \\
\text { suppliers (cooperation }\end{array}$ & $\begin{array}{c}R V S ; R Z P ; \\
D V G ; D N P ; \\
I Z G ; I N S ; \\
\quad D Z S\end{array}$ \\
\hline
\end{tabular}

\begin{tabular}{|c|c|c|}
\hline & $\begin{array}{l}\text { with whom can provide } \\
\text { higher efficiency of } \\
\text { inventory management) } \\
\text { adversely affects the } \\
\text { quality level of } \\
\text { inventory management. }\end{array}$ & \\
\hline Convergent & $\begin{array}{l}\text { Characterized mainly by } \\
\text { a minimum portfolio of } \\
\text { marketable product } \\
\text { range, which makes the } \\
\text { implementation } \\
\text { consumer of } \\
\text { "occasionally" to the } \\
\text { extent of extreme } \\
\text { emergency. } \\
\text { organization Poor } \\
\text { cooperation } \\
\text { suppliers and poor } \\
\text { marketing policy in } \\
\text { general cause an } \\
\text { insufficient level of } \\
\text { quality inventory } \\
\text { management. }\end{array}$ & $\begin{array}{l}R N G ; \\
R Z G ; \\
R N S ; \\
D N G\end{array}$ \\
\hline Sanational & $\begin{array}{l}\text { This strategy is typical } \\
\text { for commercial } \\
\text { enterprises the quality } \\
\text { level of inventory } \\
\text { management of which is } \\
\text { described as } \\
\text { unsatisfactory. The } \\
\text { demand for products has } \\
\text { unsatisfactory nature, } \\
\text { and inventory } \\
\text { management policy is } \\
\text { reflexive. Enterprises, } \\
\text { which are characterized } \\
\text { by this type of strategies } \\
\text { should reverse the policy } \\
\text { inventory management, } \\
\text { enhance marketing } \\
\text { efforts to increase the } \\
\text { demand of enterprise, } \\
\text { change the policy of } \\
\text { cooperation with } \\
\text { suppliers. This will } \\
\text { contribute to the quality } \\
\text { of inventory } \\
\text { management and change } \\
\text { of strategy for more } \\
\text { effectively. }\end{array}$ & $\begin{array}{c}R N G ; R Z G \\
\quad R N S ; \\
D N G\end{array}$ \\
\hline
\end{tabular}

* the first letter of stratagem characterizes inventory management policy, the second letter the quality level of inventory management, third the projected direction of demand for products that sells commercial enterprise. 


\section{CONCLUSION}

In the article is given the established relationship of cycle control inventory procedures, identified the main factors (each of which determines the possibility of changes in the level of inventory in the enterprise) that influence the formation of strategies for managing inventory. Considered the impact of the most important factors, which we have identified, as forecast changing of population demand, quality inventory control and to determine the private areas within the overall strategy towards inventory management, describing the pursuit of optimization of inventory in the activities of commercial enterprise.

\section{References}

[1] Blank I.A Trade management. Kyiv: Elga, Nika-Center, 2006.

[2] Voskoboeva O.V Strategy of inventory management. ZhSTU Bulletin. Economic Sciences, 2011, No. 4 (58), pp.197 - 199.

[3] Zabolotnya KA Stochastic model of inventory management of a trade enterprise. Bulletin of Berdyansk University of Management and Business, 2012, No. 2 (18), pp. 61-64.

[4] Mazaraki A.A. Economics of Trade Enterprise: Textbook for Universities. Kyiv: Khreschatyk, 1999.

[5] Olinichenko K.S Retail inventory management.Monograph. Kharkiv: Ivanchenko I. S. Publishing House, 2017.

[6] Pastukhov V.V Strategic management of the enterprise: philosophy, politics, efficiency. K.: KNEU, 2008.

\section{Creative Commons Attribution License 4.0 (Attribution 4.0 International, CC BY 4.0)}

This article is published under the terms of the Creative Commons Attribution License 4.0

https://creativecommons.org/licenses/by/4.0/deed.en_US 